\title{
Livin enhances chemoresistance in head and neck squamous cell carcinoma
}

\author{
TAE MI YOON ${ }^{1}$, SUN-AE KIM ${ }^{1}$, DONG HOON LEE ${ }^{1}$, JOON KYOO LEE ${ }^{1}$, YOUNG-LAN PARK ${ }^{2}$, \\ KYUNG-HWA LEE ${ }^{3}$, IK-JOO CHUNG ${ }^{2}$, YOUNG-EUN JOO ${ }^{2}$ and SANG CHUL LIM ${ }^{1}$ \\ Departments of ${ }^{1}$ Otorhinolaryngology-Head and Neck Surgery, ${ }^{2}$ Internal Medicine, and ${ }^{3}$ Pathology, \\ Chonnam National University Medical School, Gwanju 501-757, Republic of Korea
}

Received November 7, 2016; Accepted April 3, 2017

DOI: $10.3892 / o r .2017 .5584$

\begin{abstract}
The responsiveness of head and neck squamous cell carcinoma (HNSCC) to chemotherapy widely affects prognosis. Overcoming chemoresistance is necessary to improve prognoses in patients with advanced HNSCC. Evasion of apoptosis by cancer cells is a major cause of chemoresistance. Livin, a member of the human inhibitors of apoptosis protein family, is highly expressed in various human cancer tissues and is associated with tumor progression and poor prognosis in human cancers. The aim of the present study was to evaluate the role of Livin in the susceptibility to popularly used chemotherapeutic drugs such as cisplatin, 5-fluorouracil (FU) and docetaxel in human HNSCC cell lines (SNU1041, PCI1 and PCI50 cells). Reverse transcription polymerase chain reaction and western blotting were performed to determine mRNA and protein expression levels. Cell viability and apoptosis assays were used to assess the functional effects of small-interfering RNA-mediated knockdown of Livin. Each HNSCC cell line had different sensitivity to chemotherapeutic drugs. Livin knockdown significantly enhanced cytotoxicity to cisplatin, 5-FU and docetaxel in human HNSCC cells. Livin knockdown induced apoptosis and enhanced chemotherapyinduced apoptosis to cisplatin, 5-FU and docetaxel. Consistent with this, Livin-knockdown cells showed greater expression of cleaved caspases-3 and -7 and poly(ADP-ribose)polymerase compared with that in control cells after cisplatin, 5-FU, or docetaxel treatment. In conclusion, our results suggest that siRNA-mediated Livin knockdown enhanced the chemosensitivity of the three HNSCC cell lines to cisplatin, 5-FU and docetaxel. Although further investigations are required to support these findings, our results demonstrated that novel
\end{abstract}

Correspondence to: Dr Sang Chul Lim, Department of Otorhinolaryngology-Head and Neck Surgery, Chonnam National University Medical School, 8 Hak-Dong, Dong-Ku, Gwangju 501-757, Republic of Korea

E-mail: limsc@chonnam.ac.kr

Key words: Livin protein, drug resistance, neoplasm, apoptosis, molecular targeted therapy, head and neck squamous cell carcinoma therapeutic strategies with combined use of siRNA targeting Livin and chemotherapeutic agents may have applications in the treatment of advanced HNSCC.

\section{Introduction}

Head and neck cancer is the sixth most common carcinoma worldwide (1). Head and neck cancer accounts for approximately $3.6 \%$ of new cancer cases in the United States of America, and an estimated 59,340 new diagnoses and 12,290 deaths occurred in 2015 (1). More than $90 \%$ of head and neck cancers are squamous cell carcinomas (2). Current standard treatments for head and neck squamous cell carcinoma (HNSCC) are multimodal, including surgery, radiotherapy and chemotherapy. Despite advances in multimodality therapies, long-term survival rates remain poor, between $40-50 \%$, and further improvements in therapeutic strategies are needed, particularly in individuals with advanced-stage cancer (1-5). Thus, new strategies, such as molecular targeted therapies, are needed. Moreover, the discovery of molecular targets having synergistic effects with conventional chemotherapy is necessary because various oncogenes and underlying signaling pathways may be involved in cancer progression and treatment resistance of cancer cells.

Inhibition of apoptosis is a crucial mechanism involved in tumorigenesis and confers cancer cells with chemoresistance (6). Inhibitor of apoptosis proteins (IAPs) comprise a group of structurally related proteins with anti-apoptotic potential $(7,8)$. Livin is an important member of the human IAP family (9). Several studies have suggested that overexpression of Livin in neoplasms correlates with more aggressive behavior such as shorter disease-free survival, shorter overall survival and chemoresistance $(10,11)$. Furthermore, Livin has been shown to be highly expressed in various human cancer tissues, including melanoma, breast, colon, prostate cancer and hepatoma (10-12). Therefore, Livin has become the focus of increased research in recent years; however, little is known about the role of Livin in human HNSCC. In our previous studies, we reported that Livin is also associated with invasive and oncogenic phenotypes in human HNSCC (13-15).

The responsiveness of HNSCC to chemotherapy affects prognosis. Cisplatin-based concurrent chemoradiotherapy (CRT) has become a popular treatment that enables organ 
preservation in locally advanced HNSCC (16). A regimen of cisplatin, 5-fluorouracil (FU) and docetaxel has been established as the standard induction chemotherapy regimen for locally advanced HNSCC on the basis of large randomized phase III trials (17-19). Failure of chemotherapy resulting from drug resistance remains a challenging problem for treatment in patients with HNSCC. The role and mechanisms of Livin in chemoresistance in HNSCC have not been elucidated. Therefore, in the present study, we investigated the role of Livin in determining susceptibility to commonly used chemotherapeutic drugs, such as docetaxel, cisplatin and 5-FU, in human HNSCC cell lines. Although several studies have described that Livin contribute to the resistance of various chemotherapeutic drugs including cisplatin in various cancers (20-34), the present study is the first to demonstrate the correlation between Livin and chemoresistance in human HNSCC.

\section{Materials and methods}

Cell culture and transfection. The human HNSCC cell lines SNU1041, PCI1 and PCI50 were kindly provided by M.W. Sung (Seoul National University, Seoul, South Korea). Cells were cultured in RPMI-1640 (Invitrogen, Carlsbad, CA, USA) supplemented with $10 \%$ fetal bovine serum (FBS; HyClone Laboratories, Inc., Logan, UT, USA), $50 \mathrm{U} / \mathrm{ml}$ penicillin and $50 \mu \mathrm{g} / \mathrm{ml}$ streptomycin (Gibco, Grand Island, NY, USA) at $37^{\circ} \mathrm{C}$ in a humidified atmosphere containing $5 \% \mathrm{CO}_{2}$. Smallinterfering RNA (siRNA) was used to knockdown endogenous Livin expression in cells. Cells were transfected for $48 \mathrm{~h}$ with Livin-specific siRNA (Bioneer Corp., Daejeon, Korea) or negative control siRNA (Qiagen Sciences, Inc., Germantown, MD, USA) using Lipofectamine 2000 (Invitrogen).

RNA isolation and reverse transcription polymerase chain reaction $(R T-P C R)$. Total RNA was extracted from cells using TRIzol reagent (Invitrogen), reverse transcribed and amplified using specific primers for Livin and glyceraldehyde 3-phosphate dehydrogenase (GAPDH). Primer sequences were as follows: 5'-CACACAGGCCATCAGGACAAG-3' and 5'-ACG GCACAAAGACGATGGAC-3' (Livin $\alpha$ and Livin $\beta$ ); and 5'-ACCACAGTCCATGCCATCAC-3', 5'-TCCACCACCCTG TTGCTGTA-3' (GAPDH). PCR products were separated by electrophoresis on a $1 \%$ agarose gels containing ethidium bromide. The signals were quantified by densitometric analysis using LabWorks Image Acquisition software (UVP, LLC, Upland, CA, USA).

Protein isolation and western blot analysis. Cells were lysed in RIPA buffer. Resolved proteins were electrophoretically transferred to polyvinylidene fluoride (PVDF) membranes. Specific proteins were sequentially blotted with primary antibodies against Livin, cleaved caspase-3, cleaved caspase-7, cleaved poly(ADP-ribose)polymerase (PARP), cleaved PARP, and the X-linked inhibitor of apoptosis protein (XIAP), purchased from Cell Signaling Technology (Danvers, MA, USA) and against GAPDH (Santa Cruz Biotechnology, Santa Cruz, CA, USA) at $4^{\circ} \mathrm{C}$ overnight. The primary antibody against Livin detected Livin $\alpha(36 \mathrm{kDa})$ and Livin $\beta(34 \mathrm{kDa})$ Immunoreactive proteins were visualized using an enhanced chemiluminescence detection system with a horseradish peroxidase (HRP) substrate (Millipore, Billerica, MA, USA) and were analyzed using a LAS-4000 luminescent image analyzer (Fujifilm, Tokyo, Japan).

Chemotherapeutic drug treatment. Cell were treated with different concentrations of cisplatin (Dong-A ST, Co., Ltd., Seoul, Korea), 5-FU (JW Pharmaceutical, Seoul, Korea), or docetaxel (Boryung Pharmaceutical, Co., Ltd., Seoul, Korea) for $24 \mathrm{~h}$ at $37^{\circ} \mathrm{C}$.

Cell viability assay. Cells were seeded in 96-well plates $\left(5 \times 10^{3}\right.$ cells/well) and were then transfected the next day with Livin siRNA or negative control siRNA. After incubation for $48 \mathrm{~h}$, cell proliferation and viability were measured using an EZ-Cytox (tetrazolium salts, WST-1) cell viability assay kit (Daeil Lab Inc., Seoul, Korea). Following addition of WST-1 reagent for $1-2 \mathrm{~h}$ at $37^{\circ} \mathrm{C}$, absorbance at $460 \mathrm{~nm}$ was determined using a microplate reader (Infinite M200; Tecan, Austria GmbH, Grödig, Austria) with Magellan V6 data analysis software (Tecan). Pretreated cells served as the indicator of $100 \%$ cell viability.

Cell apoptosis assay. Apoptosis was determined using Annexin V-FITC assays. Cells were washed in phosphatebuffered saline (PBS) twice and resuspended in binding buffer (BD Biosciences, San Diego, CA, USA). Annexin V-FITC and 7-amino-actinomycin D (7-AAD; BD Biosciences) were added to the cells, and the cells were then incubated in the dark for $15 \mathrm{~min}$ and resuspended in $400 \mu \mathrm{l}$ of binding buffer. Cells were analyzed using a FACSCalibur flow cytometer (Becton-Dickinson, San Jose, CA, USA). Data analysis was performed using standard CellQuest software (BectonDickinson).

Statistical analysis. All experiments were performed independently at least three times. Experimental differences between the Livin knockdown group and control group were tested using Student's t-tests. Statistical Package for the Social Sciences (SPSS) version 20.0 (Microcal Software Inc., Chicago, IL, USA) was used for all statistical analyses. Differences with $\mathrm{P}<0.05$ were considered statistically significant.

Ethical considerations. Local research ethics committee approval was obtained from the Chonnam National University Hwasun Hospital Institutional Review Board.

\section{Results}

Response of HNSCC cell lines to chemotherapeutic drugs. To test the effects of cisplatin, 5-FU and docetaxel, we treated three HNSCC cell lines, SNU1041, PCI1 and PCI50, with different concentrations of cisplatin $(0.1-100 \mu \mathrm{g} / \mathrm{ml}), 5-\mathrm{FU}$ (2.5-100 $\mu \mathrm{g} / \mathrm{ml})$, or docetaxel $(0.1-10 \mathrm{ng} / \mathrm{ml})$ for $24 \mathrm{~h}$. Viable cells were determined by measurement of absorbance, and pretreated cells served as an indicator of $100 \%$ cell viability. Cisplatin treatment of SNU1041, PCI1 and PCI50 cells resulted in a significant reduction in cell viability in a concentration-dependent manner. PCI50 cells were more sensitive to cisplatin than SNU1041 and PCI1 cells (Fig. 1). 5-FU and docetaxel treatment of PCI1 and PCI50 cells also resulted in 

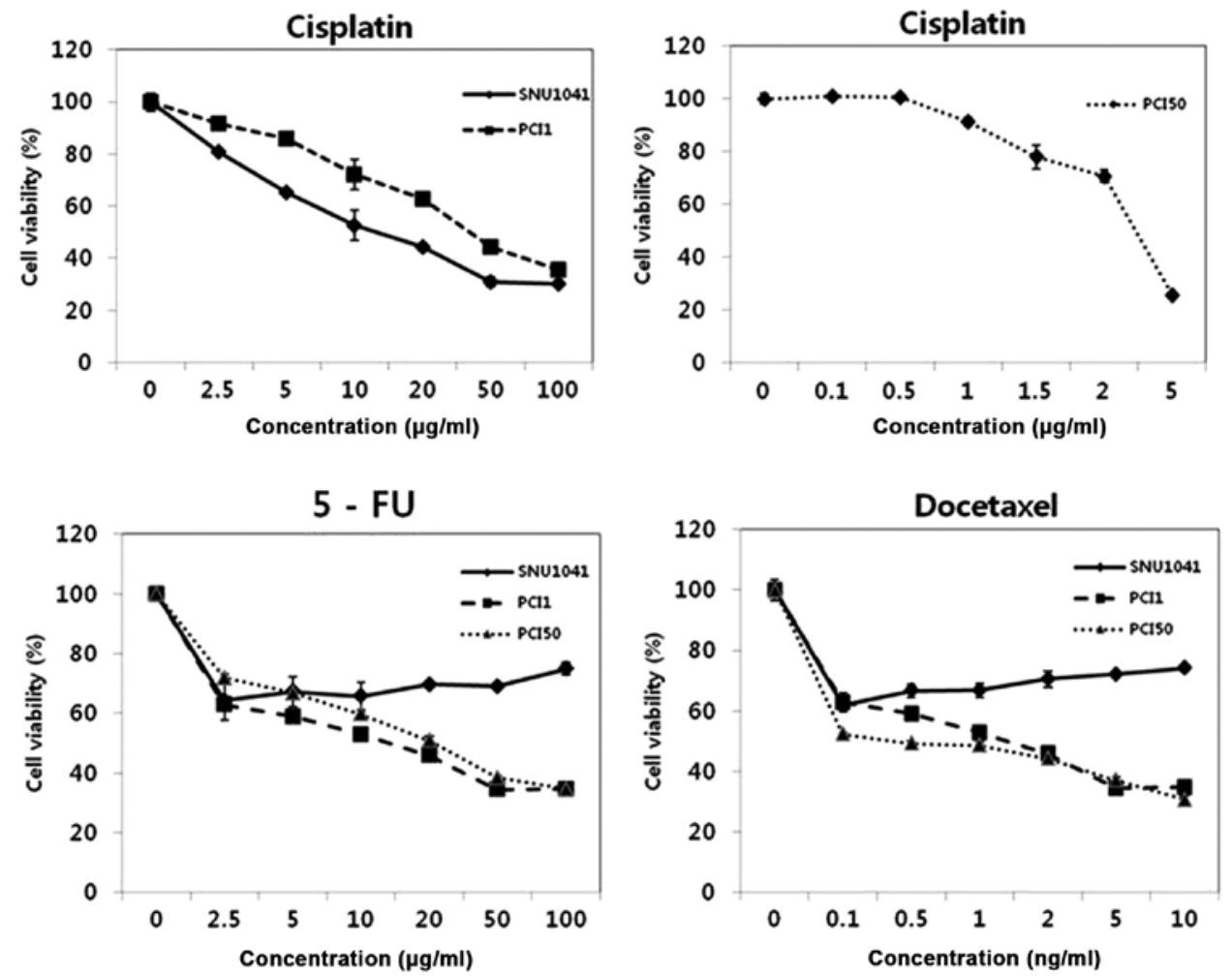

Figure 1. Response to chemotherapeutic drugs in human head and neck squamous cell carcinoma cells. Cisplatin treatment of SNU1041, PCI1 and PCI50 cells resulted in significantly reduced cell viability in a concentration-dependent manner. 5-FU and docetaxel treatment of PCI1 and PCI50 cells also resulted in significantly reduced cell viability in a concentration-dependent manner. However, SNU1041 cells exhibited resistance to 5-FU and docetaxel treatment.

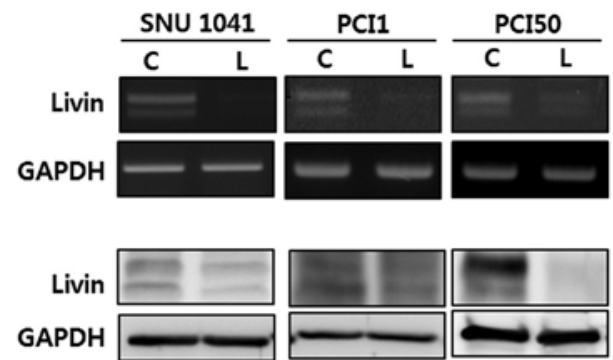

Figure 2. Expression and knockdown of Livin in human head and neck squamous cell carcinoma cells. Livin protein and mRNA expression levels were reduced following transfection with Livin siRNA in SNU1041, PCI1 and PCI50 cells compared with that in cells transfected with negative control siRNA. C, cells transfected with negative control siRNA; L, cells transfected with Livin-specific siRNA.

significantly reduced cell viability in a concentration-dependent manner. However, SNU1041 cells maintained $>60 \%$ cell viability at high concentrations of 5-FU or docetaxel. Thus, our results showed that SNU1041 cells were resistant to 5-FU or docetaxel treatment (Fig. 1).

Livin knockdown enhances the chemosensitivity of human HNSCC cells to cisplatin, 5-FU and docetaxel. To explore the role of Livin in the chemotherapy response in HNSCC cells, we used siRNA to inhibit endogenous Livin expression in human HNSCC cell lines, including SNU1041, PCI1 and PCI50 cells. Expression of Livin mRNA and protein was reduced by Livin siRNA in SNU1041, PCI1 and PCI50 cells as compared with that in cells transfected with negative control siRNA (Fig. 2).
Livin knockdown enhances the cytotoxicity of cisplatin, 5-FU and docetaxel in human HNSCC cells. To determine whether Livin knockdown affected the cytotoxicity of cisplatin, 5-FU and docetaxel in HNSCC cells, cells were transfected with Livin siRNA or negative control siRNA and then treated with cisplatin, 5-FU, or docetaxel for $24 \mathrm{~h}$. Because each HNSCC cell line had different sensitivity to chemotherapeutic drugs, SNU1041, PCI1 and PCI50 cells were treated with different concentrations of drugs. Viable cells were determined by measurement of absorbance, and pretreated cells were used as a control, indicating $100 \%$ cell viability. Cells with Livin knockdown showed reduced cell survival in response to cisplatin, 5-FU and docetaxel treatment as compared with that in negative control cells. Additionally, the viability of Livinknockdown cells was significantly lower than that of negative control cells in response to cisplatin, 5-FU and docetaxel treatment in SNU1041 cells and 5-FU or docetaxel treatment in PCI50 cells ( $\mathrm{P}<0.05$; Fig. 3). These results showed that Livin knockdown enhanced the cytotoxicity of cisplatin, 5-FU and docetaxel in human HNSCC cells.

Livin knockdown enhances chemotherapy-induced apoptosis in response to cisplatin, 5-FU and docetaxel treatment in human HNSCC cells. We addressed whether Livin knockdown enhanced chemosensitivity by measuring induction of apoptosis in SNU1041, PCI1 and PCI50 cells. After transfection with Livin siRNA or negative control siRNA, cells were treated with cisplatin, 5-FU or docetaxel for $24 \mathrm{~h}$. The combination treatment with Livin siRNA and chemotherapeutic drugs resulted in a marked increase in apoptosis as compared 

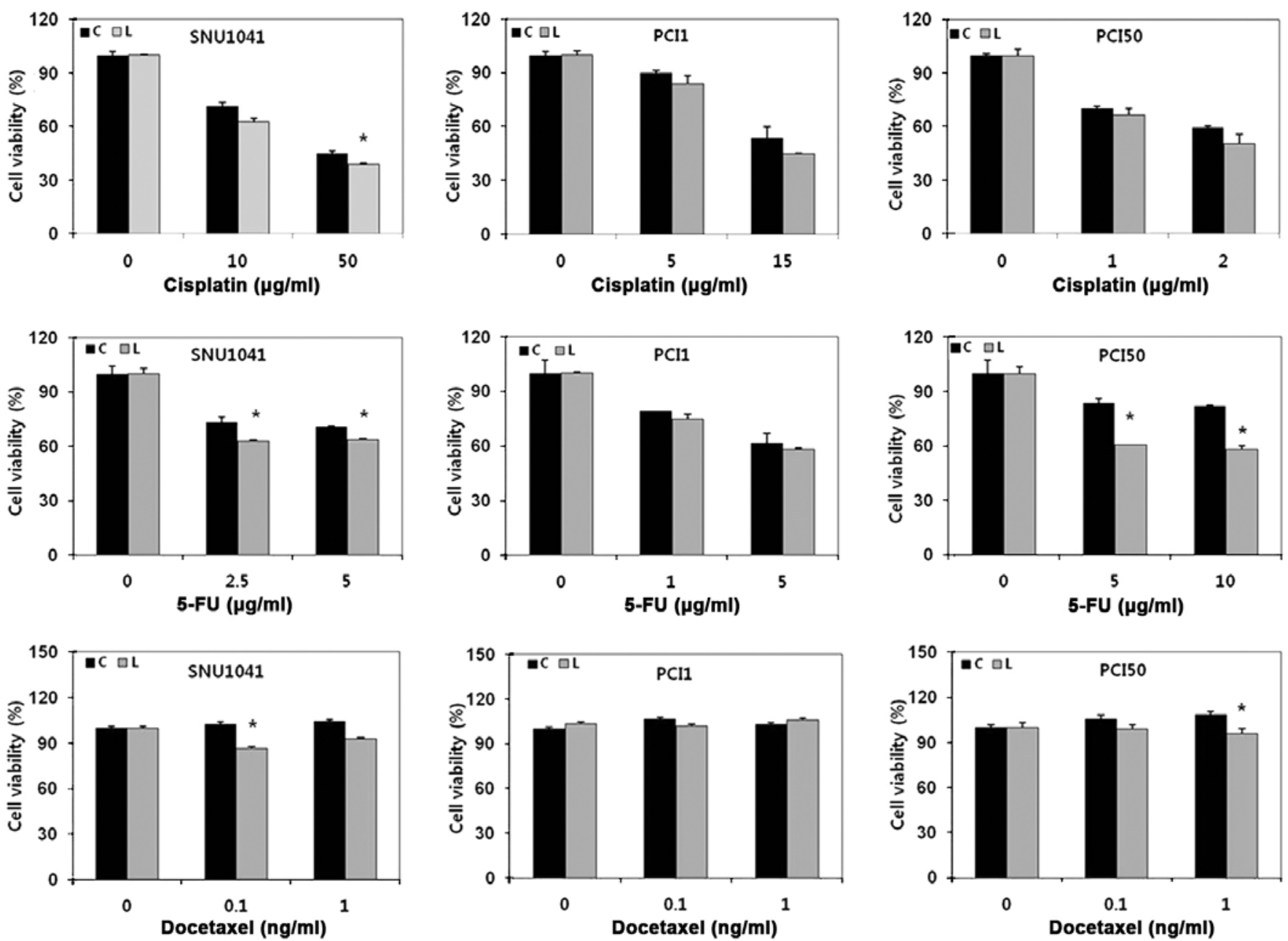

Figure 3. Effects of Livin knockdown on the cytotoxicity of chemotherapeutic drugs in human head and neck squamous cell carcinoma cells. SNU1041, PCI1 and PCI50 cells transfected with Livin-specific siRNA showed reduced cell survival in response to cisplatin, 5-FU, or docetaxel treatment compared with that in negative control cells. Viable cells were determined by measuring absorbance, and pretreated cells served as a control, indicating $100 \%$ cell viability $\left({ }^{*} \mathrm{P}<0.05\right)$. C, cells transfected with negative control siRNA; L, cells transfected with Livin-specific siRNA.

with drug treatment alone (Fig. 4). The proportions of early and late apoptotic cells induced by Livin siRNA transfection plus cisplatin were greater than those induced by negative control siRNA transfection plus cisplatin ( 32.2 vs. $49.9,53.5$ vs. 84.6 and 45.7 vs. $58.1 \%$, respectively) in SNU1041, PCI1 and PCI50 cells (Fig. 4A). The proportions of early and late apoptotic cells induced by Livin siRNA transfection plus 5 -FU were greater than that induced by negative control siRNA transfection plus 5-FU (32.4 vs. 55.5, 65.0 vs. 74.4 and 58.1 vs. $78.0 \%$, respectively) in SNU1041, PCI1 and PCI50 cells (Fig. 4A). The proportions of early and late apoptotic cells induced by Livin siRNA and docetaxel were greater than that induced by negative control siRNA transfection plus docetaxel ( 40.8 vs. $75.8,33.3$ vs. 58.2 and 44.7 vs. $62.7 \%$, respectively) in SNU1041, PCI1 and PCI50 cells (Fig. 4A). Consistent with this, Livin knockdown cells showed greater expression of cleaved caspase- 3 and -7 and PARP compared with that in control cells after cisplatin, 5-FU, or docetaxel treatment (Fig. 4B). These findings suggested that combination therapy with Livin knockdown plus chemotherapeutic drugs may have synergistic apoptosis-inducing effects in human HNSCC cells.

\section{Discussion}

HNSCC is potentially curable at an early stage using single modality therapy of either surgery or radiotherapy. However, most patients with HNSCC present with locally or locoregionally advanced disease. Surgery followed by combined chemoradiotherapy or primary concurrent chemoradiotherapy with/without induction chemotherapy is the treatment of choice in locally advanced HNSCC (35). Chemotherapy benefits patients by improving locoregional control and reducing distant metastasis (36). Thus, overcoming chemoresistance is necessary to improve prognosis in patients with advanced HNSCC.

Chemoresistance results from a variety of complicated factors, including mutations in specific drug targets, impaired drug transporters, DNA repair activation, increased drug efflux and evasion of apoptosis by cancer cells $(37,38)$. Among these mechanisms, evasion of apoptosis is considered a major cause of drug resistance since many chemotherapeutic agents act through the induction of apoptosis (6). Thus, the IAP family has become the focus of increased research related to chemoresistance in various human malignancies. 
A
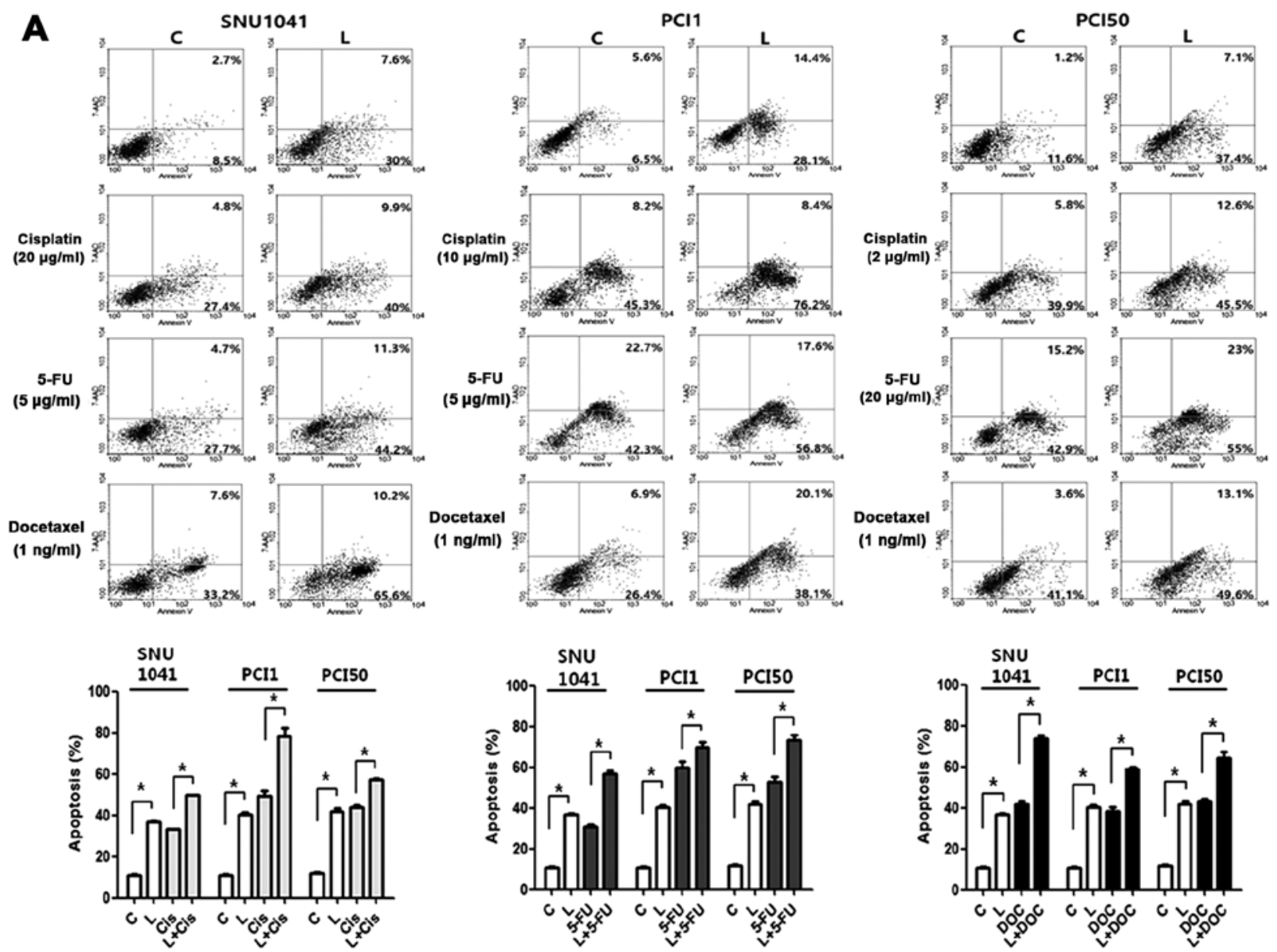

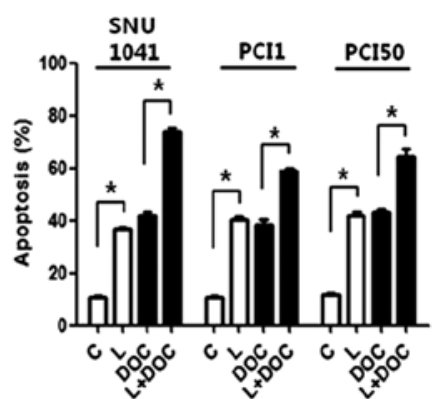

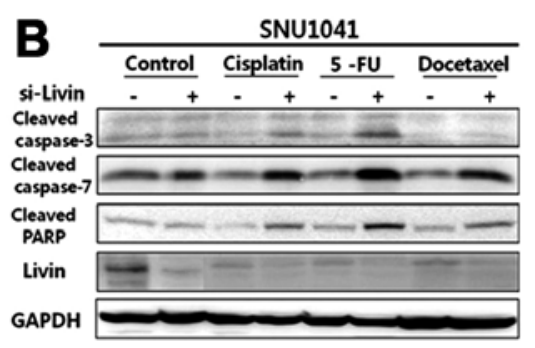

$\mathrm{PCI} 1$

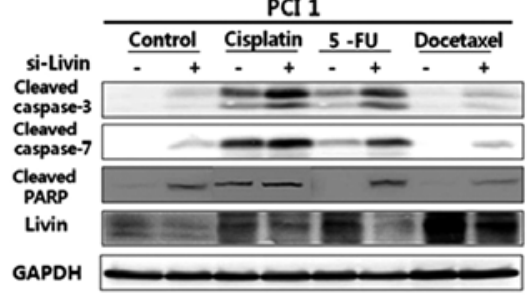

$\mathrm{PCI} 50$

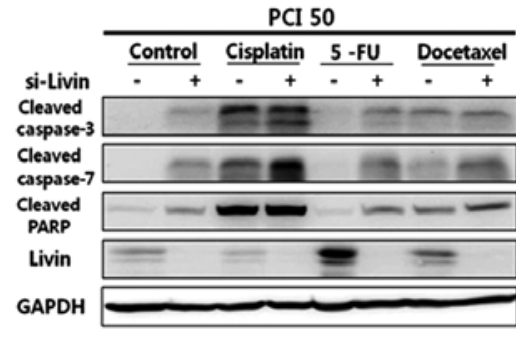

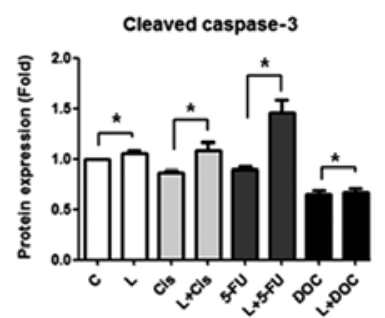
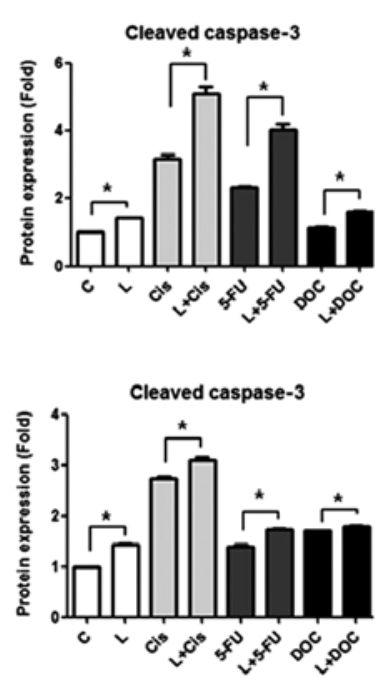
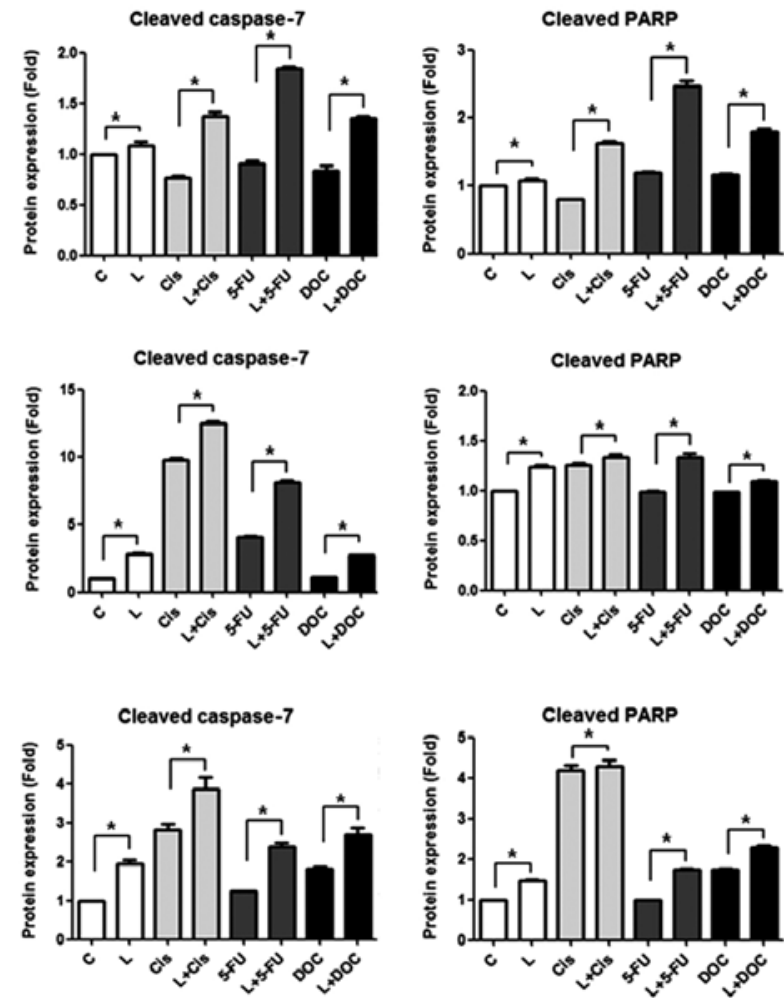

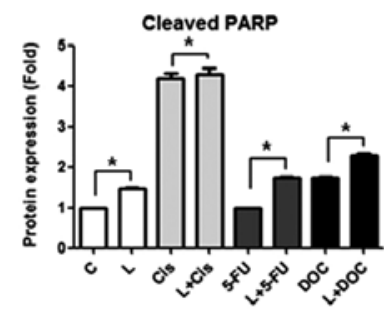

Figure 4. Effects of Livin knockdown on chemosensitivity in human head and neck squamous cell carcinoma cells. (A) Combination treatment with Livin siRNA and cisplatin, 5-FU, or docetaxel resulted in significantly increased apoptosis in SNU1041, PCI1 and PCI50 cells compared with that in control cells treated with cisplatin, 5-FU, or docetaxel alone (" $\mathrm{P}<0.05)$. (B) Livin-knockdown cells showed greater expression of cleaved caspase-3 and -7 and cleaved poly(ADP-ribose)polymerase (PARP) than did control cells after cisplatin, 5-FU, or docetaxel treatment (" $\mathrm{P}<0.05$ ). C, cells transfected with negative control siRNA; L, cells transfected with Livin-specific siRNA; Cis, cisplatin treatment; FU, 5-FU treatment; DC, docetaxel treatment. 
IAP family members include NAIP, c-IAP1, c-IAP2, XIAP, survivin, Apollon, ILP-2 and Livin $(7,9)$. These proteins contain one or more baculovirus IAP repeat (BIR) domains, which are generally required for the suppression of apoptosis, and harbor a COOH-terminal RING finger domain $(7,8,39,40)$. Livin, a recently discovered IAP, is composed of a single BIR domain and a RING motif (9). Livin has been implicated in chemoresistance in various cancers (20-34). It has been reported to play a role in resistance to cisplatin in bladder cancer, renal carcinoma, gastic cancer, hepatocellular carcinoma, lung adenocarcinoma/ non-small cell carcinoma, osteosarcoma, colon cancer and ovarian carcinoma (20-29,31). Furthermore, a few studies described that silencing Livin enhances the cytotoxic effects of one or more anticancer drugs. Wang et al (29) reported that shRNA-mediated silencing of Livin induces chemosensitivity to cisplatin and 5-FU in gastric cancer. Wang et al (30) and Oh et al (32) showed that Livin contributes to the resistance to 5-FU/vincristine/etoposide or 5-FU/leucovorin/oxaliplatin in colon cancer. Livin knockdown also increased chemosensitivity to adriamycin and cisplatin in non-small cell lung cancer (31). As these studies suggest, the effectiveness of Livin silencing in increasing sensitivity to multiple anticancer drugs is an important advantage, because different types of cancer have different chemotherapeutic regimens, and combined treatment of multiple anticancer drugs is popular in many cancers. However, the effects of Livin on chemoresistance in human HNSCC have not been studied yet. Different types of cancer have different expression of and sensitivity to specific molecular target such as Livin. Thus, we studied whether Livin is a specific molecular target to overcome the resistance of chemotherapeutic drugs commonly used in head and neck cancer.

In the present study, we showed that siRNA-mediated Livin knockdown enhanced the cytotoxicity of cisplatin, 5-FU and docetaxel in human HNSCC cells. Additionally, we found that Livin knockdown increased chemotherapy-induced apoptosis in response to cisplatin, 5-FU and docetaxel. These findings were further supported by significantly elevated levels of cleaved caspase- 3 and -7 and PARP, which are key enzymes involved in apoptosis, in Livin knockdown HNSCC cells after chemotherapy. This study provides highly valuable information because our findings were consistently observed in all three HNSCC cell lines examined and we evaluated three popular chemotherapeutic agents, which is the standard induction chemotherapy regimen in HNSCC. Our findings suggested that Livin knockdown may promote tumor cell regression, having synergistic effects when applied with cisplatin, 5-FU and docetaxel chemotherapy in human HNSCC.

There are several studies on upstream and downstream regulation of Livin involving chemoresistance in cancers. Zhu et al (22) demonstrated that miRNA-20a induces cisplatin resistance via targeting cylindromatosis (CYLD), leading to activation of nuclear factor (NF)- $\mathrm{kB}$ and downstream target Livin in gastric cancer. Activation of NF- $\mathrm{KB}$ pathway and downstream target Livin by SHANK-associated RH domain interacting protein (SHARPIN) contributed to docetaxel resistance in prostate cancer (34). In addition, Livin silencing increased cisplatin chemosensitivity involving Bcl-2 and Akt pathway in renal cell carcinoma (21). Further studies are needed to support the regulation of Livin in HNSCC.

In summary, our results demonstrated that Livin knockdown increased apoptosis and enhanced the chemosensitivity of three HNSCC cells to cisplatin, 5-FU and docetaxel. Although further studies are needed to confirm these findings, our results suggested that the novel therapeutic strategies with combined use of siRNA targeting Livin and chemotherapeutic agents may have applications in the treatment of advanced HNSCC.

\section{Acknowledgements}

The present study was supported by a grant (HCRI 14002-1) from the Chonnam National University Hwasun Hospital Institute of Biomedical Science. We thank Dr M.W. Sung (Seoul National University) for the SNU1041, PCI1 and PCI50 cell lines.

\section{References}

1. Siegel RL, Miller KD and Jemal A: Cancer statistics, 2015. CA Cancer J Clin 65: 5-29, 2015.

2. Grégoire V, Lefebvre JL, Licitra L and Felip E; EHNS-ESMOESTRO Guidelines Working Group: Squamous cell carcinoma of the head and neck: EHNS-ESMO-ESTRO Clinical Practice Guidelines for diagnosis, treatment and follow-up. Ann Oncol 21 (Suppl 5): v184-v186, 2010.

3. Choong $\mathrm{N}$ and Vokes E: Expanding role of the medical oncologist in the management of head and neck cancer. CA Cancer $\mathbf{J}$ Clin 58: 32-53, 2008.

4. Parfenov M, Pedamallu CS, Gehlenborg N, Freeman SS, Danilova L, Bristow CA, Lee S, Hadjipanayis AG, Ivanova EV, Wilkerson MD, et al; Cancer Genome Atlas Network: Characterization of HPV and host genome interactions in primary head and neck cancers. Proc Natl Acad Sci USA 111: 15544-15549, 2014.

5. Matta A and Ralhan R: Overview of current and future biologically based targeted therapies in head and neck squamous cell carcinoma. Head Neck Oncol 1: 6, 2009.

6. Igney FH and Krammer PH: Death and anti-death: Tumour resistance to apoptosis. Nat Rev Cancer 2: 277-288, 2002.

7. Deveraux QL and Reed JC: IAP family proteins - suppressors of apoptosis. Genes Dev 13: 239-252, 1999.

8. Deveraux QL, Stennicke HR, Salvesen GS and Reed JC: Endogenous inhibitors of caspases. J Clin Immunol 19: 388-398, 1999.

9. Ashhab Y, Alian A, Polliack A, Panet A and Ben Yehuda D: Two splicing variants of a new inhibitor of apoptosis gene with different biological properties and tissue distribution pattern. FEBS Lett 495: 56-60, 2001.

10. Liu B, Han M, Wen JK and Wang L: Livin/ML-IAP as a new target for cancer treatment. Cancer Lett 250: 168-176, 2007.

11. Wang L, Zhang Q, Liu B, Han M and Shan B: Challenge and promise: Roles for Livin in progression and therapy of cancer. Mol Cancer Ther 7: 3661-3669, 2008.

12. Vucic D, Stennicke HR, Pisabarro MT, Salvesen GS and Dixit VM: ML-IAP, a novel inhibitor of apoptosis that is preferentially expressed in human melanomas. Curr Biol 10: 1359-1366, 2000.

13. Kim SA, Yoon TM, Lee DH, Lee JK, Park YL, Chung IJ, Joo YE and Lim SC: Livin enhances tumorigenesis by regulating the mitogen-activated protein kinase signaling pathway in human hypopharyngeal squamous cell carcinoma. Mol Med Rep 14: $515-520,2016$.

14. Lee DH, Yoon TM, Kim SA, Park YL, Lee KH, Lim SC, Lee JK and Joo YE: Relationship between expression of Livin and the biological behavior of human oral squamous cell carcinoma. Oncol Rep 32: 2453-2460, 2014.

15. Yoon TM, Kim SA, Lee DH, Lee JK, Park YL, Lee KH, Chung IJ, Joo YE and Lim SC: Expression of Livin and the inhibition of tumor progression by Livin silencing in laryngohypopharyngeal cancer. In Vivo 28: 751-759, 2014. 
16. Pignon JP, Bourhis J, Domenge C and Designé L: Chemotherapy added to locoregional treatment for head and neck squamouscell carcinoma: Three meta-analyses of updated individual data MACH-NC Collaborative Group. Meta-Analysis of Chemotherapy on Head and Neck Cancer. Lancet 355: 949-955, 2000.

17. Hitt R, López-Pousa A, Martínez-Trufero J, Escrig V, Carles J, Rizo A, Isla D, Vega ME, Martí JL, Lobo F, et al: Phase III study comparing cisplatin plus fluorouracil to paclitaxel, cisplatin, and fluorouracil induction chemotherapy followed by chemoradiotherapy in locally advanced head and neck cancer. J Clin Oncol 23: 8636-8645, 2005.

18. Posner MR, Hershock DM, Blajman CR, Mickiewicz E, Winquist E, Gorbounova V, Tjulandin S, Shin DM, Cullen K, Ervin TJ, et al; TAX 324 Study Group: Cisplatin and fluorouracil alone or with docetaxel in head and neck cancer. N Engl J Med 357: 1705-1715, 2007.

19. Vermorken JB, Remenar E, van Herpen C, Gorlia T, Mesia R, Degardin M, Stewart JS, Jelic S, Betka J, Preiss JH, et al; EORTC 24971/TAX 323 Study Group: Cisplatin, fluorouracil, and docetaxel in unresectable head and neck cancer. $N$ Engl J Med 357: 1695-1704, 2007.

20. Yin L, Liu S, Li C, Ding S, Bi D, Niu Z, Han L, Li W, Gao D, Liu Z, et al: CYLD downregulates Livin and synergistically improves gemcitabine chemosensitivity and decreases migratory/invasive potential in bladder cancer: The effect is autophagy-associated. Tumour Biol 37: 12731-12742, 2016.

21. Wang Z, Liu S, Ding K, Ding S, Li C, Lu J, Gao D, Zhang T and Bi D: Silencing Livin induces apoptotic and autophagic cell death, increasing chemotherapeutic sensitivity to cisplatin of renal carcinoma cells. Tumour Biol 37: 15133-15143, 2016.

22. Zhu M, Zhou X, Du Y, Huang Z, Zhu J, Xu J, Cheng G, Shu Y, Liu $\mathrm{P}, \mathrm{Zhu} \mathrm{W}$, et al: miR-20a induces cisplatin resistance of a human gastric cancer cell line via targeting CYLD. Mol Med Rep 14: 1742-1750, 2016.

23. Liu F, Chang H, Xu W and Zhai Y: The effects of Livin shRNA on the response to cisplatin in HepG2 cells. Oncol Lett 10: 2957-2961, 2015.

24. Zhuang L, Shen LD, Li K, Yang RX, Zhang QY, Chen Y, Gao CL, Dong C, Bi Q, Tao JN, et al: Inhibition of livin expression suppresses cell proliferation and enhances chemosensitivity to cisplatin in human lung adenocarcinoma cells. Mol Med Rep 12: 547-552, 2015.

25. Zou AM, Wang HF, Zhu WF, Wang FX and Shen JJ: Effect of RNAi-mediated silencing of Livin gene on biological properties of colon cancer cell line LoVo. Genet Mol Res 13: 3832-3841, 2014.

26. Ding ZY, Liu GH, Olsson B and Sun XF: Upregulation of the antiapoptotic factor Livin contributes to cisplatin resistance in colon cancer cells. Tumour Biol 34: 683-693, 2013.

27. Li X, Fan S, Li L, Wang L, Fan G, Zhao Q and Li Y: RNA interference-mediated knockdown of Livin suppresses cell proliferation and invasion and enhances the chemosensitivity to cisplatin in human osteosarcoma cells. Int J Oncol 43: 159-168, 2013.
28. Liu X, Wang A, Gao H, Yuan Z and Jiao Y: Expression and role of the inhibitor of apoptosis protein livin in chemotherapy sensitivity of ovarian carcinoma. Int J Oncol 41: 1021-1028, 2012.

29. Wang TS, Ding QQ, Guo RH, Shen H, Sun J, Lu KH, You SH, Ge HM, Shu YQ and Liu P: Expression of livin in gastric cancer and induction of apoptosis in SGC-7901 cells by shRNA-mediated silencing of livin gene. Biomed Pharmacother 64: 333-338, 2010.

30. Wang X, Xu J, Ju S, Ni H, Zhu J and Wang H: Livin gene plays a role in drug resistance of colon cancer cells. Clin Biochem 43: 655-660, 2010

31. Yuan D, Liu L, Xu H and Gu D: The effects on cell growth and chemosensitivity by livin RNAi in non-small cell lung cancer. Mol Cell Biochem 320: 133-140, 2009.

32. Oh BY, Kim KH, Chung SS and Lee RA: Silencing the livin gene enhances the cytotoxic effects of anticancer drugs on colon cancer cells. Ann Surg Treat Res 91: 273-277, 2016.

33. Liang SR, Hu GR, Fang LJ, Huang SJ, Li JS, Zhao MY and Meng MJ: CpG oligodeoxynucleotides enhance chemosensitivity of 5-fluorouracil in HepG2 human hepatoma cells via downregulation of the antiapoptotic factors survivin and livin. Cancer Cell Int 13: 106, 2013.

34. Zhang Y, Huang H, Zhou H, Du T, Zeng L, Cao Y, Chen J, Lai Y, Li J, Wang G, et al: Activation of nuclear factor $\kappa \mathrm{B}$ pathway and downstream targets survivin and livin by SHARPIN contributes to the progression and metastasis of prostate cancer. Cancer 120: 3208-3218, 2014.

35. Forastiere AA: Head and neck cancer: Overview of recent developments and future directions. Semin Oncol 27 (Suppl 8): 1-4, 2000.

36. Ma J, Liu Y, Huang XL, Zhang ZY, Myers JN, Neskey DM and Zhong LP: Induction chemotherapy decreases the rate of distant metastasis in patients with head and neck squamous cell carcinoma but does not improve survival or locoregional control: A meta-analysis. Oral Oncol 48: 1076-1084, 2012.

37. Endo T, Abe S, Seidlar HB, Nagaoka S, Takemura T, Utsuyama M, Kitagawa M and Hirokawa K: Expression of IAP family proteins in colon cancers from patients with different age groups. Cancer Immunol Immunother 53: 770-776, 2004.

38. Kim DK, Alvarado CS, Abramowsky CR, Gu L, Zhou M, Soe MM, Sullivan K, George B, Schemankewitz E and Findley HW: Expression of inhibitor-of-apoptosis protein (IAP) livin by neuroblastoma cells: Correlation with prognostic factors and outcome. Pediatr Dev Pathol 8: 621-629, 2005

39. Deveraux QL, Roy N, Stennicke HR, Van Arsdale T, Zhou Q, Srinivasula SM, Alnemri ES, Salvesen GS and Reed JC: IAPs block apoptotic events induced by caspase- 8 and cytochrome c by direct inhibition of distinct caspases. EMBO J 17: 2215-2223, 1998.

40. Deveraux QL, Takahashi R, Salvesen GS and Reed JC: X-linked IAP is a direct inhibitor of cell-death proteases. Nature 388 : 300-304, 1997. 